Rakenteiden Mekaniikka

Vol. 52, Nro 1, 2019, s. 23-37

http://rakenteidenmekaniikka.journal.fi/index

https://doi.org/10.23998/rm.74512

(C) 2019 kirjoittajat

Vapaasti saatavilla CC BY 4.0 -lisenssin mukaisesti.

\title{
Sprinklerilaitteiston luotettavuuden vaikutus teräsrakenteiden palomitoitukseen
}

\author{
Mikko Salminen $^{1}$, Mikko Nieminen ja Mikko Malaska
}

Tiivistelmä. Automaattiset sprinklerilaitteistot ovat tehokas keino pienentää rakennuspaloihin liittyviä riskejä. Ympäristöministeriön uusi asetus rakennusten paloturvallisuudesta on avannut uusia mahdollisuuksia sisällyttää sprinklereiden vaikutus rakennussuunnitteluun. Useissa kohteissa on voitu osoittaa, että esimerkiksi teräsosien palosuojauksen määrää voidaan vähentää merkittävästi tai jopa jättää kokonaan pois, silloin kun sprinklerijärjestelmä toimii suunnitellulla tavalla. Toimintavarmat ja palonkestävät suunnitteluratkaisut edellyttävät, että sprinklereille käytetyt luotettavuustasot sekä oletettuun palonkehitykseen perustuvat suunnittelumenetelmät ovat kattavasti perusteltuja. Tämä artikkeli esittelee tutkimuksen, jolla pyrittiin määrittämään sprinklerilaitteistojen luotettavuustasoja tyypillisissä rakennuskohteissa sekä arvioimaan mahdollisia hyötyjä voidaan saavuttaa, jos sprinklerijärjestelmän luotettavuus otetaan huomioon teräsrakenteiden rakennesuunnitteluun.

Avainsanat: sprinklerilaitteisto, luotettavuus, paloturvallisuussuunnittelu, toiminnallinen palomitoitus

Vastaanotettu 9.9.2018. Hyväksytty 17.1.2019. Julkaistu verkossa 11.7.2019.

\section{Johdanto}

Automaattiset sprinklerilaitteistot ovat yksi tehokkaimmista aktiivisen palosuojauksen keinoista ja siten tärkeä osa rakennusten paloturvallisuussuunnittelun kokonaisuutta. Niiden avulla voidaan vähentää sekä palokuolemia että tulipaloista aiheutuvia aineellisia vahinkoja. Sprinklerilaitteistojen kokonaisluotettavuus voidaan nykyisin ottaa huomioon oletettuun palonkehitykseen perustuvassa toiminnallisessa paloturvallisuussuunnittelussa ja, mikäli laitteistolle voidaan osoittaa riittävän korkea toimintavarmuustaso, voi laitteiston olemassaolo pienentää myös rakennushankkeen kustannuksia. Tapauksesta riippuen muutaman prosenttiyksikön ero sprinklerilaitteiston luotettavuudessa voi vaikuttaa suunniteltavan rakenteen kustannuksiin kymmeniä prosentteja.

${ }^{1}$ Vastuullinen kirjoittaja: mikko.salminen@ rakennusteollisuus.fi 
Määritettäessä sprinklerilaitteistojen kokonaisluotettavuutta tulee laitteistojen toimintavarmuuden (operational reliability) lisäksi huomioida myös laitteiston saatavilla oleminen (availability) ja toimintatehokkuus (performance reliability) [9]. Toimintavarmuus mittaa todennäköisyyttä, jolla laitteisto toimii tarvittaessa. Saatavissa olo mittaa todennäköisyyttä, että laitteisto on käytettävissä tarvittaessa. Sprinklerilaitteisto voi olla pois käytöstä esimerkiksi laitteiston huollon tai rakennuksessa tehtävän korjaustyön takia [10]. Saatavissa oloa voidaan valvoa esimerkiksi kytkemällä laitteiston komponentteihin, erityisesti sulkuventtiileihin, automaattiset hälyttimet, jotka varoittavat, jos laitteisto ei ole toimintavalmiudessa. Toimintatehokkuus puolestaan mittaa todennäköisyyttä, jolla järjestelmän toimiessa se toimii tehokkaasti. Useat tutkimukset ovat osoittaneet, että kun sprinklerit aktivoituvat, niiden tehokkuus on erittäin hyvä, 96-98 \% [14]. Laitteiston kokonaisluotettavuus kuvaa siis todennäköisyyttä, jolla laitteisto on käytettävissä, komponentit ovat toimintakunnossa ja laitteisto pystyy tehokkaasti sammuttamaan tai rajoittamaan tulipalon. Se voidaan määrittää edellä esitettyjen kolmen tekijän tulona.

Sprinklerilaitteistojen luotettavuutta tutkitaan tyypillisesti kahdella eri tavalla: systeemipohjaisesti tapahtumatilastojen avulla tai komponenttipohjaisesti käyttäen vikapuuanalyysiä. Systeemipohjaisessa lähestymisessä koko laitteiston toimintavarmuusarvio perustuu tilastoihin, jotka on koottu sprinklerilaitteistojen toiminnasta aiemmissa palotilanteissa. Komponenttipohjaisessa ratkaisumallissa laitteiston toimintavarmuusarvio muodostetaan kohdekohtaisesti sprinklerilaitteiston kytkentäkaavioiden perusteella muodostettujen vikapuiden sekä laitteiston osana toimivien yksittäisten komponenttien luotettavuusdatan perusteella.

Sprinklerilaitteistojen luotettavuutta koskevia systeemipohjaisia tutkimuksia on raportoitu paljon, mutta tutkimuksissa esitetyt laitteistojen toimintavarmuudet vaihtelevat merkittävästi. Jos tarkastellaan sellaisia tulipaloja, joissa palo on ollut riittävän suuri aktivoimaan sprinklerit, eri tutkimuksissa raportoidut toimintavarmuuden arvot ovat vaihdelleet välillä 86-98 \% [1-4]. Erot arvioissa johtuvat mm. tutkimuksissa käytetyistä lähdeaineistoista sekä erilaisista tulkinnoista siitä, millaiset palot otetaan mukaan tutkimukseen ja mikä katsotaan onnistuneeksi sammutukseksi. Monia palotilastoja tai tutkimusten aineistoja ei ole dokumentoitu niin täsmällisesti, että laitteistojen toimimattomuuden syitä olisi niiden perusteella mahdollista enää märittää. Näiden puutteiden vuoksi kansainvälisten systeemipohjaisten tutkimustulosten soveltaminen rakennusten paloturvallisuussuunnittelussa on vaikeaa.

Sprinklerilaitteistojen ja -järjestelmien luotettavuutta voidaan arvioida myös komponenttipohjaisella menetelmällä käyttäen vikapuita, joissa yksilöidään kohdekohtaisen laitteiston keskeiset komponentit, arvioidaan niiden vikaantumistodennäköisyydet sekä kytketään ne järjestelmän toiminnan mukaiseksi puurakenteeksi [5,6]. Vikapuuhun sisällytettäviä komponentteja voivat olla esimerkiksi vesilähteet, sprinklerit, putkistot ja venttiilit. Esimerkkejä komponenttimenetelmän soveltamisesta on esitetty useissa lähteissä $[6,8]$.

Rajallinen kokemus toiminnallisten menetelmien käytöstä ja epävarmuus sprinklerilaitteistojen tehokkuudessa ovat olleet tähän asti oletettuun palonkehitykseen perustuvan suunnittelun kehitystä rajoittavia tekijöitä eikä mitoitusmenetelmien soveltamisesta ole vielä olemassa yhtenäistä käytäntöä. Tampereen teknillisessä korkeakoulussa 
toteutetussa diplomityötutkimuksessa selvitettiin tyypillisten rakennuskohteiden sprinklerilaitteistojen luotettavuustasoja sekä luotettavuuden vaikutusta oletettuun palonkehitykseen perustuviin suunnitteluratkaisuihin. Tutkimuksessa oli mukana myös alan keskeisiä asiantuntijoita TTY:n palotekniikan tutkimusryhmän lisäksi Palotekninen Insinööritoimisto Markku Kauriala Oy, Ramboll Finland Oy, Promist Oy, Puutuoteteollisuus ry sekä Teräsrakenneyhdistys ry. Tässä artikkelissa esitetään tutkimuksen päätulokset.

\section{Sprinklerilaitteistojen luotettavuus}

\section{Systeemipohjainen tutkimus}

Systeemipohjaisessa luotettavuusarviossa tutkittiin Suomessa vuosina 1996-2016 sattuneita rakennuspaloja. Tutkimus tehtiin hyödyntäen pelastustoimen resurssi- ja onnettomuustilasto PRONTO:a [15]. PRONTO-tietokantaan on tilastoitu vuodesta 1996 lähtien kaikki pelastuslaitokselle ilmoitetut onnettomuudet. Tutkimukseen poimittiin PRONTO:sta tapaukset, jotka olivat sattuneet yleissuojaavalla sprinklerilaitteistolla suojatuissa rakennuksissa. Tutkimuksesta jätettiin pois tapaukset, joissa lämpötila ei noussut riittävän korkealle sprinklerien reagoimiseksi ennen kuin tulipalo sammuu itsestään tai se sammutetaan joko alkusammutuksella tai pelastuslaitoksen toimesta. Pois jätettiin myös tapaukset, jotka sattuivat sprinklerilaitteistolla suojatun alueen ulkopuolella.

PRONTO:ssa automaattisen sammutuslaitteiston toiminnan onnistuminen on jaettu seuraaviin kategorioihin:

- sammutti

- rajoitti

- toiminta tai vaikutus puutteellista

- sammutuslaitteisto ei toiminut

Lähtökohtaisesti tapaukset, joissa sprinklerilaitteisto sammutti tai rajoitti palon, laskettiin onnistuneiksi. Vastaavasti tapaukset, joissa oli merkitty sprinklerilaitteiston toiminta tai vaikutus puutteelliseksi tai sammutuslaitteisto ei toiminut, laskettiin epäonnistuneiksi. Kaikkien tapausten onnettomuus- ja rakennusselosteet käytiin kuitenkin läpi ja sen perusteella arvioitiin lopullisesti, täyttikö tapaus onnistuneen sammutuksen kriteerin eli kykenikö sprinklerilaitteisto estämään palon leviämisen rakenteita uhkaavaksi. Mikäli onnettomuus- ja rakennusselosteissa oli epäselvyyksiä sprinklerilaitteiston toiminnan osalta, kysyttiin lisätietoja rakennuksen käyttäjiltä. Kuudessa tapauksessa toiminnan onnistuminen ei selvinnyt, joten ne laskettiin epäonnistuneiksi tapauksiksi. Tutkimuksen tulokset on esitetty taulukossa 1.

PRONTO-tietokantaan perustuvan systeemipohjaisen tutkimuksen tulos sprinklerilaitteistojen luotettavuudelle oli 98,1\%. Tutkimuksessa tarkasteltiin kokonaisluotettavuutta eli siinä huomioitiin laitteiston toimintavarmuus, toimintatehokkuus ja saatavissa olo. Kuudessa tapauksessa epäonnistuminen aiheutui laitteiston toimintavarmuudesta ja kolmessa tapauksessa siitä, ettei laitteisto ollut käytössä. Kuudessa tapauksessa toiminnan epäonnistumisen syy ei selvinnyt. Toimintatehokkuudesta aiheutuneita 
epäonnistumisia ei ollut lainkaan, vaan aina jos sprinklerilaitteisto reagoi tulipaloon, se onnistui sammuttamaan tai rajoittamaan palon.

Taulukko 1: PRONTO-tietokantaan perustuvan systeemipohjaisen tutkimuksen tulokset.

\begin{tabular}{lcccc}
\hline PRONTO-luokittelu & Onnistui & Epäonnistui & Ei tietoa & $\begin{array}{c}\text { Tapaus ei täytä } \\
\text { kriteerejä }\end{array}$ \\
\hline $\begin{array}{l}\text { Sammutti tai rajoitti } \\
\text { Toiminta puutteellista }\end{array}$ & 755 & & 3 & 15 \\
$\begin{array}{l}\text { Laitteisto ei toiminut } \\
\text { - palo rakennuksen tai suojatun } \\
\text { alueen ulkopuolella tai laitteisto } \\
\text { ei ehtinyt toimia }\end{array}$ & 6 & 4 & 57 \\
$\begin{array}{l}\text { - inhimillinen virhe tai laitteisto } \\
\text { ei toiminut muusta syystä } \\
\text { Yhteensä }\end{array}$ & 761 & 9 & 6 & 1920 \\
\hline Luotettavuusprosentti & $98,1 \%$ & & 3 & 2045 \\
\hline
\end{tabular}

\section{Komponenttipohjainen tutkimus}

Komponenttipohjaisessa tutkimuksessa sprinklerilaitteiston luotettavuutta arvioidaan vikapuumallin avulla. Vikapuumallia muodostettaessa ensimmäisenä määritetään ei-toivottu tapahtuma, jota tutkitaan. Sprinklerilaitteiston tapauksessa se on: "Oletetun toiminnan epäonnistuminen tulipalon sattuessa". Laitteiston yksittäisen komponentin vikaantuminen voi suoraan aiheuttaa ei-toivotun tapahtuman tai tehdä niin yhdistelmänä muiden komponenttien vikaantumisen kanssa. Vikapuussa yhdistelmiä kuvataan loogisilla JA (AND) sekä TAI (OR) porteilla. Porttityyppien valinnat ja vikapuun rakenne luonnollisesti heijastavat laitteiston reaktioita komponenttien vikaantumisiin.

Tässä tutkimuksessa komponenttipohjaista menetelmää sovellettiin teräsrakenteisen kauppakeskuksen sprinklerilaitteiston luotettavuuden määrittämiseen. Vikapuu muodostettiin kohteen sprinklerilaitteiston kytkentäkaavion perusteella. Vikapuussa huomioitiin kaikki komponentit, joiden vikaantuminen voi johtaa laitteiston vikaantumiseen. Lisäksi tehokkaan sammuttamisen epäonnistuminen huomioitiin arvioimalla todennäköisyyttä, jolla aukeavien sprinkleripäiden lukumäärä ylittää mitoitusarvon, mikä johtaa liian vähäiseen vapautuvaan vesimäärään yksittäisestä suuttimesta. Seuraavassa kuvassa (Kuva 1) on esitetty osa muodostetusta vikapuusta. Vikapuussa ympyrällä on kuvattu JA-portteja, joissa laitteiston vikaantuminen edellyttää kaikkien rinnakkaisten komponenttien tai komponenttiryhmien vikaantumista ja kolmiolla TAI-portteja, joissa yhdenkin rinnakkaisen komponentin tai komponenttiryhmän vikaantuminen johtaa laitteiston vikaantumiseen. 


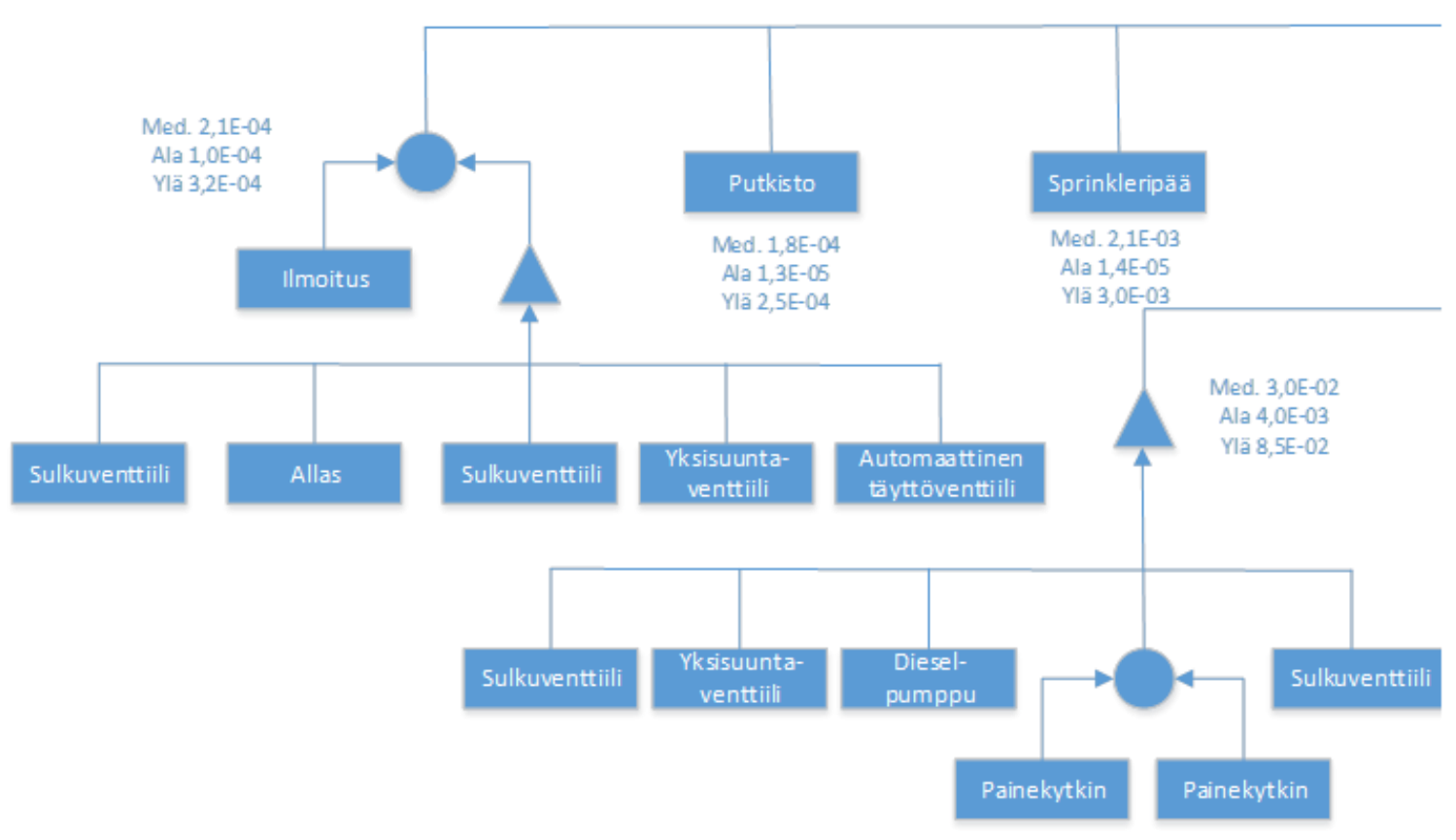

Kuva 1. Ote komponenttipohjaisessa tutkimuksessa käytetystä vikapuusta.

Komponenttien vikaantumistodennäköisyydet vikapuuta varten määritettiin hyödyntämällä aiemmissa tutkimuksissa esitettyjä vikaantumisen todennäköisyyttä kuvaavia arvoja. Osa arvoista oli annettu suoraan vikaantumisen todennäköisyytenä tarvittaessa ja osa vikaantumistaajuutena. Vikapuuhun tarvitaan vikaantumisen todennäköisyys tarvittaessa, joten vikaantumistaajuudet muutettiin vikaantumistodennäköisyyksiksi. Kun komponentin vikaantumistaajuus, $\lambda$ ja tarkastusväli, $t$ tiedetään, voidaan vikaantumistodennäköisyys laskea seuraavalla kaavalla

$$
P=1-e^{-\lambda t}
$$

Tarkastusväli, $t$ määritettiin kullekin komponentille erikseen Sprinklerilaitteiston kunnossapito-ohjelman laadintaohjeessa [16] annettujen ohjeistusten mukaan. Komponenteille annetut vikaantumistodennäköisyyksien arvot vaihtelivat todella paljon eri lähteiden välillä. Osasta tutkimuksista oli saatavilla vain tulokset eikä itse tutkimukseen ollut pääsyä, joten eri lähteissä annettujen lukuarvojen luotettavuutta oli vaikea arvioida. Komponenttien vikaantumistietoja oli saatavilla sen verran niukasti, että kaikki löydetyt vikaantumistodennäköisyyksien arvot päätettiin ottaa mukaan tutkimukseen. Käytetyt vikaantumistodennäköisyyden arvot on esitetty taulukossa 2 [7,8,10,17-23].

Laitteiston tehokkaan toiminnan onnistumista voidaan arvioida esimerkiksi avautuvien sprinkleripäiden määrän perusteella. Mikäli avautuvien sprinkleripäiden lukumäärä ylittää suunnitteluarvon, yksittäisestä sprinkleripäästä vapautuva vesimäärä voi jäädä suunniteltua vähäisemmäksi. Tässä tutkimuksessa hyödynnettiin Jukka Hietaniemen kauppakeskuskohteelle määrittämää todennäköisyyttä sille, että avautuvien sprinkleri- 
päiden lukumäärä ylittää mitoitusarvon [24]. Lähteenä on käytetty useita kansainvälisiä tutkimuksia [7], [25-32]. Todennäköisyyden vaihteluväli oli $1,9 \times 10^{-4}-2,1 \times 10^{-3}$ (mediaani 7,5×10-4).

Vikapuussa ei otettu huomioon sprinklerilaitteiston saatavilla oloa, koska jos laitteisto irtikytketään, tulee pelastusviranomaisen kanssa sopia tarvittavista tilapäisistä suojaus- ja turvallisuustoimenpiteistä. Näitä toimenpiteitä ovat esimerkiksi kiinteistön vartioinnin järjestäminen, palovaaraa aiheuttavien töiden kieltäminen ja sammutusvalmiuden tehostaminen pelastuslaitoksen sammutusyksiköllä [16].

Eri lähteistä kerätyt vikapuulaskennan lähtöarvot, komponenttien vikaantumistodennäköisyydet, vaihtelivat paljon. Tästä syystä tutkimuksessa päädyttiin käyttämään Monte Carlo -simulointia. Monte Carlo -simulointi sopii juuri erityisen hyvin ongelmille, joissa lähtöarvojen tiedetään olevan epätarkkoja. Siinä lähtöarvoista muodostetaan jakauma, josta poimitaan lukuarvoja satunnaisesti ja suoritetaan niille tarvittavat laskelmat. Simulaatio suoritetaan useita kertoja, minkä jälkeen voidaan tehdä päätelmiä suoritettujen laskelmien tuloksista.

Tässä tutkimuksessa jokaisen komponentin vikaantumistodennäköisyyksistä muodostettiin erillinen kolmiojakauma. Kolmiojakauma muodostettiin siten, että komponentin vikaantumistodennäköisyysarvojen mediaani on kolmiojakauman huippu. Kolmio kuvaa todennäköisyysjakaumaa ja sen kokonaispinta-ala on siis 1. Jokaisen komponentin kolmiojakaumasta poimittiin satunnaisesti vikaantumistodennäköisyyden arvo ja suoritettiin vikapuumallin mukainen laskenta. Simulaatio toistettiin 1000 kertaa.

Komponenttipohjaisessa tutkimuksessa lopputulokseksi saatu teräsrakenteisen ostoskeskuksen sprinklerilaitteiston kokonaisluotettavuus vaihteli välillä 98,6 \% - 99,6 $\%$. Lopputuloksessa on otettu huomioon kaikki luotettavuuden kolme komponenttia: toimintavarmuus, saatavilla oleminen ja toimintatehokkuus. Näin korkea luotettavuustaso antaa usein mahdollisuuden mitoituspalokuorman pienentämiseen, mikä taas vaikuttaa edullisesti mm. teräsrakenteiden palonsuojaustarpeeseen sekä rakentamisen kustannuksiin. Laitteistolle laskennallisesti saavutetun korkean luotettavuusprosentti hyödyntäminen edellyttää inhimillisten virheiden, kuten huollon laiminlyömisen tai laitteistojen vääränlaisten asetusten, eliminointia. Tutkimus osoittaa, että inhimillisellä tekijällä on merkittävä vaikutus luotettavuustasoon ja se tulee ottaa aina huomioon kohdekohtaisesti.

\section{Sprinklerilaitteiston ylläpidon vaikutus toimintavarmuuteen}

Sprinklerilaitteiston kaikkien komponenttien toimintavarmuus riippuu merkittävästi kyseisen komponentin tarkastusvälin pituudesta. Vaikutuksen osoittamiseksi sprinklerilaitteiston luotettavuutta tutkittiin eri tarkastusväleillä. Tätä tutkimusta varten tarvitaan vikaantumistaajuudet eri komponenteille. Valitettavasti painekytkimelle ja valvontailmoitukselle löytyi vain suoraan arvoja vikaantumistodennäköisyydelle tarvittaessa eikä lainkaan vikaantumistaajuuksia. Painekytkimen ja valvontailmoituksen vikaantuminen jätettiin kokonaan pois tämän tutkimuksen vikapuusta, joten tuloksia ei voida suoraan hyödyntää sprinklerilaitteiston luotettavuuden arviointiin, mutta niiden avulla voidaan vertailla tarkastusvälin pituuden vaikutusta luotettavuuden arvoon.

Ensimmäinen arvio tehtiin tarkastusväleillä, joita suositellaan Finanssialan Keskusliiton vuonna 2007 julkaisemassa sprinklerilaitteiston kunnossapito-ohjelman laadinta- 
ohjeessa. Tarkastusvälit eri komponenteille olivat 1-3 kuukautta. Muut arviot tehtiin 3:n, 6:n, 12:n ja 24:n kuukauden tarkastusväleillä. Tulokset on esitetty taulukossa 3.

Tämän tarkastelun perusteella kauppakeskuksen tapauksessa vikaantumisen todennäköisyys on 10,3-kertainen, jos laitteiston komponenttien tarkastusväli on 24 kuukautta verrattuna FK:n ohjeen suosittelemiin tarkastusväleihin. Vaikka tulokset ovat suuntaa antavia, voidaan niiden perusteella nähdä huollon erittäin suuri vaikutus laitteiston luotettavuuteen.

Taulukko 2: Komponenttien vikaantumistodennäköisyyksiä [7,8,10,17-23].

\begin{tabular}{lc}
\hline Komponentti & Vikaantumistodennäköisyys tarvittaessa \\
\hline Yleinen vesijohto & $8.0 \times 10^{-6}-3.8 \times 10^{-4}$ \\
Vesiallas & $0.0-2.3 \times 10^{-4}$ \\
Sulkuventtiili & $1.7 \times 10^{-4}-2.5 \times 10^{-3}$ \\
Hälytysventtiili & $3.3 \times 10^{-6}-2.0 \times 10^{-3}$ \\
Sähkömoottorikäyttöinen pumppu & $5.0 \times 10^{-5}-1.3 \times 10^{-2}$ \\
Dieselmoottorikäyttöinen pumppu & $1.9 \times 10^{-4}-8.4 \times 10^{-2}$ \\
Sprinkleriputkisto (per m) & $2.8 \times 10^{-7}-1.3 \times 10^{-5}$ \\
Sprinkleripää & $1.4 \times 10^{-5}-3.0 \times 10^{-3}$ \\
Yksisuuntaventtiili & $1.1 \times 10^{-3}-2.5 \times 10^{-3}$ \\
Käynnistyspainekytkin & $9.0 \times 10^{-4}-7.8 \times 10^{-3}$ \\
Valvontailmoitus & $3.3 \times 10^{-2}$ \\
\hline
\end{tabular}

Taulukko 3. Tarkastusvälin pituuden vaikutus kauppakeskuksen sprinklerilaitteiston luotettavuuteen.

\begin{tabular}{cc}
\hline Tarkastusväli & Luotettavuus \\
\hline $1-3 \mathrm{kk}$ & $98,9 \%$ \\
$3 \mathrm{kk}$ & $98,4 \%$ \\
$6 \mathrm{kk}$ & $97,0 \%$ \\
$12 \mathrm{kk}$ & $94,1 \%$ \\
$24 \mathrm{kk}$ & $88,7 \%$ \\
\hline
\end{tabular}

\section{Teräsrakenteiden mitoitusmenetelmä}

Useimpien maiden (ml. Suomi) palomääräysten mukaan kantavien rakenteiden riittävä palonkestävyys voidaan osoittaa kahdella vaihtoehtoisella tavalla [33]:

- Perustuen valmiiksi annettuihin luokkiin ja lukuarvoihin, jotka perustuvat rakenteiden kestävyyteen standardin ISO 834 [34] mukaisessa standardipalossa (ns. taulukkomitoitus). Tällöin mitoituskriteerinä on, että kantavat rakenteet kestävät 
vaaditun minuuttimäärän standardipalossa, esimerkiksi 30 minuuttia, kun vaatimus on R 30 .

- Perustuen oletettuun palonkehitykseen, jolloin rakenteet suunnitellaan kestämään mitoituspalot, jotka kattavat riittävällä todennäköisyydellä rakennuksessa esiintyvät palotapahtumat (ns. toiminnallinen palomitoitus). Tällöin mitoituskriteerinä tyypillisesti on, että rakenne kestää mitoituspalon kokonaisuudessaan, mukaan lukien palon jäähtymisvaihe. Joissain tapauksissa (1-2-kerroksiset henkilöturvallisuuden kannalta ei-vaativat rakennukset) riittävänä voidaan pitää myös sitä, että rakenteet eivät riittävällä luotettavuudella sorru poistumisen turvaamiseen, pelastustoimintaan ja palon hallintaan saamiseen tarvittavana aikana [14].

Oletettuun palonkehitykseen perustuvalla mitoituksella määritetyn suunnitteluratkaisun voidaan osoittaa olevan riittävän paloturvallinen kahdella eri tavalla: perustuen absoluuttiseen tai suhteelliseen riskitasoon [33]. Kummassakin tapauksessa tarvitaan kvantitatiivinen riskianalyysi. Käytännössä pienehköissä kohteissa ja/tai mikäli kohteen palokuormat ovat hyvin tiedossa, riskianalyysi voi olla myös kvalitatiivinen ja mitoituspalot voidaan määrittää yhteistyössä viranomaisten kanssa.

Absoluuttisen paloriskin määrittäminen on hyvin haasteellista, koska siihen liittyy paljon epävarmuuksia (mm. palotehon kasvu, palon leviäminen ja palokunnan toimenpiteet). Näitä epävarmuuksia voidaan hallita jollain tasolla soveltamalla palotilastoja ja Monte Carlo -laskentaa, mutta toisaalta myös absoluuttisen riskin suurimman sallitun arvon määrittäminen on vaikeaa. Näin ollen, monissa tapauksissa on käytännöllisempää osoittaa suunnitteluratkaisun riittävä paloturvallisuus vertailemalla riskitasoja seuraavalla tavalla:

- Toiminnallisen palomitoituksen mukaisen ratkaisun riskien määritys

- Taulukkomitoituksen mukaisen ratkaisun riskien määritys (hyväksyttävä ratkai$\mathrm{su})$

- Määritettyjen riskitasojen vertailu. Suunniteltuun ratkaisuun liittyvien riskien on oltava pienempiä tai yhtä suuria kuin hyväksyttävään ratkaisuun liittyvien riskien

Kuvassa 2 on esitetty esimerkki tapahtumapuusta, jota voidaan hyödyntää edellä mainitussa menettelyssä. Tapahtumapuulla kuvataan tapahtumaketjua tulipalon sytyttyä. Alkutapahtumana on tilanne, joka ilman onnistuneita turvallisuustoimenpiteitä voi johtaa ei-toivottuihin seurauksiin. Tässä tapauksessa ei-toivottu seuraus on kantavan rakenteen sortuma. Kyseinen tapahtumapuu on hyvin yksinkertainen, mutta siitä käy hyvin ilmi, kuinka sprinklauksen vaikutus voidaan ottaa huomioon kvantitatiivisessa, vertailevassa riskianalyysissä ja näin ollen rakenteiden oletettuun palonkehitykseen perustuvassa mitoituksessa. 


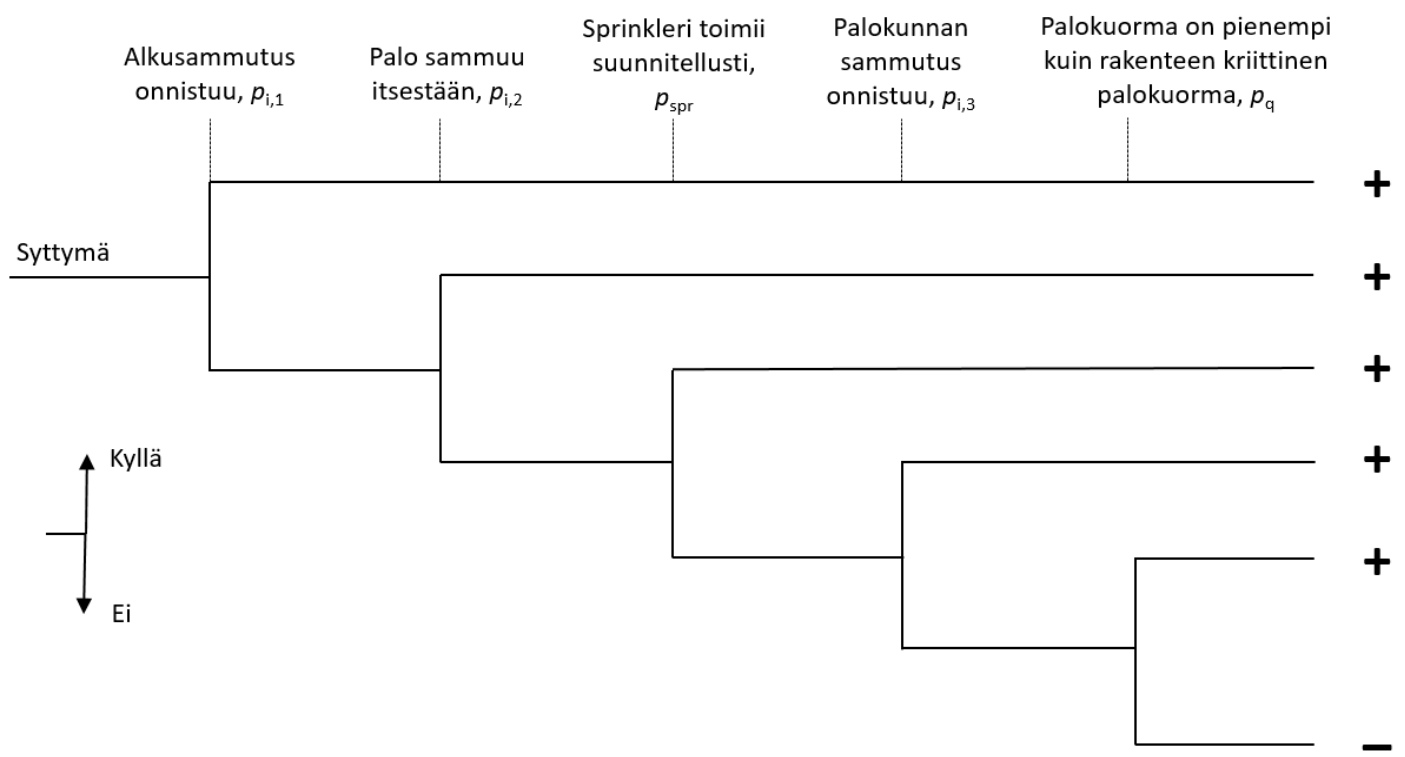

Kuva 2. Esimerkki paloriskianalyysin tapahtumapuusta. Kantavien rakenteiden sortumaan johtava tapahtumaketju on merkitty " -":lla ja sortumattomuuteen johtavat tapahtumaketjut "+":1la.

Todennäköisyydet alkusammutuksen onnistumiselle $\left(p_{\mathrm{i}, 1}\right)$, palon itsesammumiselle $\left(p_{\mathrm{i}, 2}\right)$ ja palokunnan sammutuksen onnistumiselle $\left(p_{\mathrm{i}, 3}\right)$ saadaan tilastoista, joita Suomesta löytyy hyvin, esim. [35,36]. Kriittinen palokuorma kullekin rakenteelle siinä tapauksessa, että sprinkleri ei toimi (mikäli sprinklattu rakennus), on määritettävä käyttäen tapaukseen soveltuvia palon ja rakenteen mitoitus- ja/tai simulointimenetelmiä, kuten esimerkiksi virtauslaskentaohjelmistot, parametriset palomallit ja elementtimenetelmämallit, Eurokoodin yksinkertaisemmat mitoitusmenetelmät. Luonnollisesti kriittinen palokuorma riippuu tarkasteltavasta rakenteesta ja sen palosuojauksesta. Todennäköisyys, että kriittinen palokuorma ylittyy, on määritettävä tilastollisesti. Suunniteltavaan kohteeseen liittyvä palokuormajakauma on siis oltava riittävällä tarkkuudella tiedossa. Esimerkiksi lähteestä [12] löytyy tilastojen perusteella johdetut palokuormajakaumat asuin-, toimisto- ja liikerakennuksille. Lisäksi samassa ohjeessa on esitetty myös muiden käyttötarkoitusryhmiin kuuluvien tilojen keskimääräisiä palokuormia sekä menetelmä, kuinka niistä voidaan muodostaa arvio palokuormajakaumalle. Standardista SFS-EN 1991-1-2 [37] löytyy myös joitakin palokuormafraktiilien arvoja.

Kuvassa 2 esitetyssä tapahtumapuuformulaatiossa oletetaan, että tapahtumien todennäköisyydet eivät ole riippuvaisia toisistaan. Lisäksi siinä oletetaan, että jos sprinkleri toimii palon sattuessa suunnitellulla tavalla, rakenteellisen sortuman vaaraa palossa ei ole. Tämän olettamuksen tueksi löytyy teräsrakenteille tehtyjä polttokokeita ja simulointeja, esimerkiksi [38,39]. On kuitenkin tärkeää, että tämän olettamuksen paikkansapitävyys arvioidaan erikseen kohdekohtaisesti, varsinkin silloin kun mitoitettavan kohteen palokuorma on suuri ja/tai rakenteiden palonkesto on pieni.

Kun taulukkomitoituksen mukainen hyväksyttävä todennäköisyys rakenteiden sortumiselle palossa $\left(p_{\text {col }}\right)$ on määritetty, voidaan käytettävä mitoituspalokuorman fraktiili $\left(p_{\mathrm{q}}\right.$, tilastojen mukainen osuus palokuormista, joka alittaa kohteen mitoituksessa 
käytettävän palokuorman arvon) määrittää siten, että toiminnallisen mitoituksen mukaiselle ratkaisulle saadaan korkeintaan vastaava sortumistodennäköisyys. Näin sprinklerijärjestelmän luotettavuus $\left(p_{\text {spr }}\right)$ on suoraan yhteydessä käytettävään mitoituspalokuormaan. Kaavassa (2) on esitetty rakenteiden palossa sortumisen todennäköisyyden laskenta, kun käytetään Kuvan 2 mukaista tapahtumapuuta. Kaava (3) on johdettu yhtälöstä (2) ja sillä voidaan määrittää toiminnallisessa palomitoituksessa käytettävän mitoituspalokuorman fraktiili. On syytä huomata, että käytettäessä näin määritettyä mitoituspalokuormaa, sprinklereiden jäähdyttävää vaikutusta ei oteta huomioon analyyseissä, vaan oletetaan, että se ei mitoittavassa tapauksessa toimi.

$$
\begin{aligned}
& p_{\text {col }}=\left(1-p_{i, 1}\right) \cdot\left(1-p_{i, 2}\right) \cdot\left(1-p_{i, 3}\right) \cdot\left(1-p_{s p r}\right) \cdot\left(1-p_{q}\right) \\
& p_{q}=1-\frac{p_{c o l}}{\left(1-p_{i, 1}\right) \cdot\left(1-p_{i, 2}\right) \cdot\left(1-p_{i, 3}\right) \cdot\left(1-p_{s p r}\right)}
\end{aligned}
$$

Edellä kuvatun kaltainen laskentaproseduuri soveltuu esimerkiksi tapauksiin, joissa luokkiin ja lukuarvoihin (ns. taulukkomitoitukseen) perustuva ratkaisu ei vaadi sprinklausta ja teräsrakenteet tulisi palosuojata raskaasti. Käytettäessä tällaisessa kohteessa sprinklausta, voidaan edellä kuvatulla menetelmällä yksinkertaisesti osoittaa rakenteiden palossa sortumisen riskin olevan hyväksyttyä arvoa parempi pienemmällä palosuojauksella. Tämä edellyttää, että menetelmään liittyvät parametrit, ml. Sprinklauksen luotettavuus ja kohteeseen liittyvä palokuormajakauma, tiedetään riittävällä tark-kuudella.

\section{Teräsrunkoisen kauppakeskuksen mitoitusesimerkki}

Tässä kappaleessa havainnollistetaan sprinklauksen luotettavuuden merkitystä rakenteellisessa palomitoituksessa esimerkin avulla. Esimerkissä tarkastellaan mikä on sprinklauksen luotettavuuden (kun välillä 90 - 99,3\%) merkitys rakenteen paloluokkavaatimukseen ja teräsrakenteiden kustannuksiin.

Esimerkkikohteena on kauppakeskus, jonka kantavat kattorakenteet suunniteltiin toteutettavan teräsristikoin. Kohteen alustavan paloteknisen suunnittelun ml. Teräsristikoiden toiminnallinen palomitoitus teki Palotekninen insinööritoimisto Markku Kauriala Oy. Kohteen riskianalyysi tehtiin samalla periaatteella kuin tässä artikkelissa kuvattu menettely. Tapahtumapuu oli kuitenkin tässä tapauksessa hieman monimutkaisempi ja siinä hyödynnettiin myös Monte Carlo -laskentaa palon kasvun, leviämisen ja palokunnan toiminnan huomioon ottamiseksi. Riskianalyysissä otettiin huomioon myös kohteen suuri palo-osastokoko ja siitä muodostunut riski laajempaan rakenteelliseen sortumaan palossa. Kohteen palotilanteet simuloitiin käyttäen FDS-ohjelmaa (Fire Dynamics Simulator [40]). Teräsprofiilien kriittisien lämpötilojen määrityksessä käytettiin pääosin standardin SFS-EN 1993-1-2 [41] yksinkertaisia kaavoja. On syytä huomata, että rakenteen lopullinen palomitoitus on tarkoitus tehdä käyttäen kehittyneempiä laskentamenetelmiä (kuten FEM-laskentaohjelma SAFIR [42]). Näin rakenteiden kokonaiskäyttäytymisestä saadaan realistisempi kuva ja esim. lämpölaajenemisen ja suurten muodonmuutosten vaikutukset voidaan ottaa huomioon. Alustavissa tarkasteluissa ristikoiden profiilit eivät olleet vielä tiedossa, joten standardin SFS-EN 1993-1-2 mukaisia sauvakohtaisia mitoitusmenetelmiä pidettiin riittävän tarkkoina alustavien 
paloluokkien määrittämiseen. Teräksisillä vaakarakenteilla (etenkin palkit) on testein ja laskelmin todettu olevan usein huomattavasti enemmän kapasiteettia palossa, kuin yksinkertaiset laskentamenetelmät antavat tulokseksi, kun sen liitokset ja liittyvät rakenteet mitoitetaan kestämään suurista siirtymistä aiheutuvat voimat $[43,44]$. Näin ollen alustavien tulosten oletetaan antavan varmalla puolella olevia tuloksia ristikoiden palonkestävyyksien suhteen.

Tehtyjen analyysien perusteella saatiin määritettyä kriittiset palokuormat teräsristikoille, joiden paloluokka oli R $0, \mathrm{R} 15, \mathrm{R} 30, \mathrm{R} 45$ ja R 60. Tässä tapauksessa hyväksyttävä (luokkien ja lukuarvojen mukainen) ratkaisu olisi ollut $\mathrm{R} 60$ teräsristikot ja sprinklausta ei olisi tällöin vaadittu. Lisäksi palo-osastojen olisi taulukkomitoituksen mukaan tullut olla huomattavasti pienempiä kuin toiminnallisen mitoituksen mukaisessa ratkaisussa. Kaikille tarkastelluille teräsristikoille määritettiin todennäköisyys sortua palossa sen paloluokan funktiona. Todennäköisyydet $p_{\mathrm{i}, 1}, p_{\mathrm{i}, 2}$ ja $p_{\mathrm{i}, 3}$ otettiin suoraan tilastoista [35,36]. Näiden todennäköisyyksien oletettiin olevan yhtä suuria sekä sprinklatussa että sprinklaamattomassa tapauksessa. Kohteen sprinklerisysteemin luotettavuuden mitoitusarvoksi määritettiin komponettipohjaisella menetelmällä 98,6-99,6 \%. Tässä kappaleessa esitetyssä vertailutarkastelussa luotettavuuden maksimiarvoksi on valittu 99,3\%.

Taulukossa 4 on esitetty sprinklerisysteemin luotettavuuden vaikutus käytettävään mitoituspalokuormaan, teräsristikoiden paloluokkavaatimukseen ja palosuojauksen osuuteen teräsristikoiden kokonaiskustannuksissa. Eri paloluokkien kustannusvaikutukset on otettu Metallirakentamisen tutkimuskeskuksen tekemästä tutkimuksesta [45], jossa optimoitiin teräsristikoita, joilla oli eri paloluokkavaatimus. On syytä huomata, että taulukossa 4 esitetyt kustannukset ovat suuntaa antavia arvioita, jotka todellisuudessa riippuvat paljon rakenteesta ja konepajan tai kohteen sijainnista. Paloluokituksia R 45 ja R 75 käytetään käytännössä harvoin, mutta tässä tapauksessa ne ovat mukana tulosten havainnollistamiseksi. Taulukossa 4 esitetyt arvot ovat teoreettisia, jotka johtavat tässä artikkelissa esitettyjä laskentamentelmiä käyttäen samaan rakenteelliseen paloturvallisuustasoon. Monesti käytännön palosuunnittelussa lopullinen suunnitteluratkaisu muodostuu yhdessä suunnittelijan laskelmien ja viranomaisten sekä mahdollisen kolmannen osapuolen näkemysten pohjalta.

Taulukosta 4 nähdään, että sprinklerin luotettavuudella on suuri merkitys rakenteilta vaadittuun paloluokitukseen ja teräsrakenteiden kustannuksiin. Paloluokka R 60 on taulukkomitoituksen mukainen ratkaisu, mikä tulosten perusteella on oletetusti varmalla puolella ja se vastaa likimain tilannetta, jossa sprinklerin luotettavuus olisi 92-96\%.

\section{Yhteenveto}

Tässä tutkimuksessa tutkittiin rakennusten automaattisten sprinklerilaitteistojen luotettavuutta sekä selvitettiin luotettavuuden vaikutusta paloteknisiin suunnitteluratkaisuihin ja niiden kustannuksiin. Luotettavuutta arvioitiin kahdella menetelmällä. Systeemipohjainen luotettavuusarvio perustuu sprinklerilaitteistojen toiminnan onnistumiseen toteutuneissa palotilanteissa ja tutkimuksessa hyödynnettiin PRONTO-tietokannan tapahtumatilastoja vuosina 1996-2016 Suomessa tapahtuneista rakennuspaloista. Komponenttipohjaisessa ratkaisumallissa laitteiston toimintavarmuusarvio muodostetaan kohde- 
kohtaisesti sprinklerilaitteiston kytkentäkaavioiden perusteella muodostettujen vikapuiden avulla. Tässä tutkimuksessa menetelmää sovellettiin teräsrakenteisen ostoskeskuksen sprinklerilaitteistoon. Molemmat menetelmät antoivat laitteistoille korkean luotettavuusarvion. Systeemipohjaisen tutkimuksen tulos kokonaisluotettavuudelle oli 98,1\% ja komponenttimenetelmällä määritetty luotettavuus vaihteli välillä 98,6-99,6 \% . Näin korkea luotettavuustaso antaa usein mahdollisuuden kohteen mitoituspalokuorman pienentämiseen, mikä taas vaikuttaa edullisesti $\mathrm{mm}$. teräsrakenteiden palonsuojaustarpeeseen sekä rakentamisen kustannuksiin. Sprinklerin luotettavuudella on suuri merkitys palosuojauksen ja teräsrakenteiden kustannuksiin. Tutkitun ostoskeskuksen tapauksessa taulukkomitoituksen mukaisessa ratkaisussa palosuojauksen arvioitu osuus teräsristikon kokonaiskustannuksista oli 80-95\%, kun taas toiminnallisen mitoituksen mukainen osuus on vain 10-30\%. Tutkimus osoittaa, että sprinklereiden luotettavuutta on mahdollista arvioida ja, että toiminnallinen palomitoitus yhdessä perustellun luotettavuusarvion kanssa antavat mahdollisuuksia innovatiivisille rakenneratkaisuille sekä merkittäviin säästöihin rakennuskustannuksista.

Tässä tutkimuksessa esitetty toiminnallisen palomitoituksen ratkaisu perustuu kunnossapitosuunnitelman mukaisiin huoltoväleihin ja kuten tehty herkkyysanalyysi osoitti, niistä poikkeaminen aiheuttaa selvän turvallisuustason pienenemisen. Turvallisuustason arvioiminen on erittäin vaikeaa sen jälkeen, kun suunnittelussa käytetystä ohjelmasta poiketaan.

Taulukko 4. Sprinklerilaitteiston luotettavuuden vaikutus kohteen mitoituspalokuormaan, teräsristikoiden luokkavaatimukseen sekä palosuojauksen osuuteen ristikoiden kustannuksista.

\begin{tabular}{|l|c|c|c|c|c|c|c|c|}
\hline Sprinklerin luotettavuus & $99,3 \%$ & $99 \%$ & $98 \%$ & $97 \%$ & $96 \%$ & $94 \%$ & $92 \%$ & $90 \%$ \\
\hline $\begin{array}{l}\text { Mitoituspalokuorma } \\
{\left[\mathrm{MJ} / \mathrm{m}^{2}\right]}\end{array}$ & 490 & 594 & 771 & 866 & 931 & 1019 & 1080 & 1127 \\
\hline Vaadittu luokkavaatimus & $\mathrm{R} 15$ & $\mathrm{R} 30$ & $\mathrm{R} 45$ & $\mathrm{R} 45$ & $\mathrm{R} 60$ & $\mathrm{R} 60$ & $\mathrm{R} 60$ & $\mathrm{R} 75$ \\
\hline $\begin{array}{l}\text { Palosuojauksen osuus } \\
\text { ristikoiden kustannuksista }\end{array}$ & $10 \%$ & $30 \%$ & $55 \%$ & $55 \%$ & $80 \%$ & $80 \%$ & $80 \%$ & $95 \%$ \\
\hline
\end{tabular}

\section{Viitteet}

[1] Ahrens, M. 2017. U.S. Experience with Sprinklers. National Fire Protection

[2] Efficiency and effectiveness of sprinkler systems in the United Kingdom: An analysis from fire service Data. 2017. Optimal Economics

[3] Nystedt, F. (2011). Verifying fire safety design in sprinklered buildings. (LUTVDG/TVBB-3150-SE; Vol. 3150). Lund University, Dept of Fire Safety Engineering and System Safety.

[4] William, E., Koffel, P.E. (2005). Reliability of automatic sprinkler systems. Revised September 2005. A paper comissioned by the Alliance for Fire and Smoke Containment and Control, Inc. 
[5] Hauptmanns, U., Marx, M., Grünbeck S. (2008). Availability analysis for a fixed wet sprinkler system. Fire Safety Journal 43 (2008), pp. 468-476.

https://doi.org/10.1016/j.firesaf.2008.03.002

[6] Frank, K.M., Gravestock, N., Spearpoint, M., Fleischmann, C. (2013). A review of sprinkler system effectiveness studies. Fire Science Reviews. Vol. 2. Issue 1. Article 6. Springer. https://doi.org/10.1186/2193-0414-2-6

[7] Rönty, V., Keski-Rahkonen, O., Hassinen, J. (2004). Reliability of sprinkler systems. Exploration and analysis of data from nuclear and non-nuclear installations. VTT Working Papers 15.

[8] Moinuddin, K., Thomas, I., Chea, S. (2008) Estimating the Reliability of Sprinkler Systems in Australian High-rise Office Buildings. Centre for Environmental Safety and Risk Engineering. doi:10.3801/IAFSS.FSS.9-515

[9] Budnick, E. K. 2001. Automatic Sprinkler System Reliability, Fire Protection Engineering, Winter 2001, Issue No. 9

[10] Marsh (2008). Effectiveness of Fire Safety Systems for Use in Quantitative Risk Assessments. New Zealand Fire Service Commission.

[11] Hietaniemi, J., Mikkola, E. (2010). Design Fires for Safety Engineering. VTT Working Papers 139. VTT Technical Research Centre of Finland

[12] Finnish Wood Research Oy 2015: Palotekninen Insinööritoimisto Markku Kauriala Oy (2015). Puukerrostalon palosuunnitteluohje - toiminnallinen suunnittelu. Finnish Wood Research Oy.

[13] Mikkola, E., Holopainen, S. (2017). Puukerrostalon palotekniikka. Kareliaammattikorkeakoulun julkaisuja C, Raportteja: 46. Saatavissa (viitattu 5.9.2018): http://www.theseus.fi/handle/10024/133111

[14] Ympäristöministeriön asetus rakennusten paloturvallisuudesta 848/2017, 2017. Saatavissa (viitattu 5.9.2018): https://www.finlex.fi/fi/laki/alkup/2017/20170848

[15] PRONTO (2017). Pelastustoimen resurssi- ja onnettomuustilasto. Saatavissa (viitattu 5.9.2018): https://prontonet.fi/

[16] Sprinklerilaitteiston kunnossapito-ohjelman laadintaohjeet. 2007. Finanssialan Keskusliitto.

[17] Brammer, H. (2010). Examination into the Reliability of Secondary Water Supplies. Fire Engineering Research Report 10/10. University of Canterbury.

[18] Feeney, M. (2001) Accounting for Sprinkler Effectiveness in Performance Based Design of Steel Buildings for Fire. Fire Engineering Research Report 01/12. University of Canterbury.

[19] Watanabe, A. (1979). Effectiveness of Active Fire Protection Systems. Systems Approach to Fire Safety in Buildings. CIB Symposium. Vol 2, pp. 1-11

[20] Moelling, D.S., Sideris, A.G., and Hockenbury, R.W. (1980). Reliability of Fire Protection Systems in Nuclear Plants. Thermal Reactor Safety, in Proceedings of the American Nuclear Society/European Nuclear Society Topical Meeting. Knoxville, TN. April 6-9.

[21] Finucane, M., Pickney, D. (1989). Reliability of Fire Protection and Detection Systems. United Kingdom Atomic Energy Authority. University of Edinburgh, Scotland.

[22] Nash, P., Young, R.A. (1991). Automatic Sprinkler Systems for Fire Protection, 2nd edn. Paramount Publishing Limited. 
[23] OREDA (2002). Offshore Reliability Data Handbook, 4th Edition. OREDA Participants.

[24] Hietaniemi, J. (2017) Sprinkelerilaitteiston toimintatehokkuus (Haastattelu, Toukokuu 2017)

[25] Marryatt, H.W. (1988). Fire: A Century of Automatic Sprinkler Protection in Australia and New Zealand, 1886-1986. Australian Fire Protection Association.

[26] Assemblée Plenière des societés d'assurance dommages (1997). APSAD.

[27] Kirchner, U. (1996). BVFA \& VdS.

[28] Kokkala, M. (1997). Sprinkler Statistics for Finland. VTT.

[29] Automatic Sprinkler Performance Tables (1970). 1970 Edition. Fire Journal 64 (1970), pp. 35-39.

[30] Linder, K.W. (1993). Field reliability of fire detection systems. NIST 5264: Balanced Design Concepts Workshop. National Institute of Standards and Technology.

[31] Lessons of a high-rise fire (1976). Fire International. Vol. 5. Issue 51, pp. 59-64.

[32] Solomon, R.E. (1997). Automatic Sprinkler Systems. Fire Protection Handbook, $18^{\text {th }}$ Edition. National Fire Protection Association

[33] Fire safety in timber buildings (2010). Technical guideline for Europe. SP Technical Research Institute of Sweden. SP Trätek, Tukholma.

[34] ISO 834. Fire Resistance Tests - Elements of Building Constructions. International Standard ISO 834. 1975.

[35] Tillander, K., Oksanen, T. \& Kokki, E. 2009. Paloriskin arvioinnin tilastopohjaiset tiedot [Statistical data for fire risk assessment], VTT Tiedotteita - Research Notes 2479. VTT, Espoo. (In Finnish).

[36] Tillander, K. 2004. Utilisation of statistics to assess fire risks in buildings. Espoo, VTT Building and Transport. VTT Publications 537.

[37] Eurokoodi 1: Rakenteiden kuormat. Osa 1-2: Yleiset kuormat. Palolle altistettujen rakenteiden rasitukset. Suomen standardoimisliitto SFS ry, SFS-EN 1991-1-2+AC, Helsinki, Finland, 2003

[38] Outinen, J. \& Kansa, J. 2009. Fire protection of steel structures using sprinkler systems. Proceedings - Nordic Steel Construction Conference 2009: Malmö, Sweden, September 2-4, 2009.

[39] Outinen, J. \& Vaari, J. 2013. Fire Protection of Tall Steel Columns using Water Sprinklers. Application of Structural Fire Engineering, 19-20 April 2013, Prague, Czech Republic.

[40] McGrattan, K., Hostikka, S., McDermott, R., Floyd, J., Weinschenk, C., Overholt, K. 2013. Fire Dynamics Simulator, User's Guide. NIST Special Publication 1019, Sixth Edition. National Institute of Standards and Technology.

[41] Eurokoodi 3: Teräsrakenteiden suunnittelu. Osa 1-2: Yleiset säännöt. Rakenteen palomitoitus. Suomen standardoimisliitto SFS ry, SFS-EN 1993-1-2, Helsinki, Finland, 2006

[42] Gernay, T., Franssen, J.M. 2017. Modeling structures in fire with SAFIR. Theoretical background and capabilities. Journal of Structural Fire Engineering, Vol. 8, issue 3, pp. 300-323. https://doi.org/10.1108/JSFE-07-2016-0010

[43] Yin, Y.Z. \& Wang, Y.C. 2005. Analysis of catenary action in steel beams using a simplified hand calculation method, Part 1: theory and validation for non-uniform 
temperature distribution. Journal of Constructional Steel Research 61, 2005, pp. 183-211. https://doi.org/10.1016/j.jcsr.2004.07.002

[44] Yin, Y.Z. \& Wang, Y.C. 2005. Analysis of catenary action in steel beams using a simplified hand calculation method, Part 2: validation for non-uniform temperature distribution. Journal of Constructional Steel Research 61, 2005, pp. 213-234. https://doi.org/10.1016/j.jcsr.2004.07.003

[45] Jokinen, T., Mela, K., Tiainen, T., Heinisuo, M. 2016. Optimization of tubular trusses using intumescent coating in fire. Rakenteiden Mekaniikka (Journal of Structural Mechanics), Vol. 49, No 4, 2016, pp. 160-175

Mikko Salminen

Teräsrakenneyhdistys ry

Eteläranta 10, 00131 Helsinki

mikko.salminen@rakennusteollisuus.fi

Mikko Nieminen

Palotekninen Insinööritoimisto Markku Kauriala Oy

Korkeakoulunkatu 1, 33720 Tampere

mikko.nieminen@kauriala.fi

Mikko Malaska

Tampereen teknillinen yliopisto

PL 600, 33101 Tampere, Finland

mikko.malaska@tut.fi 